\title{
Analysis Of Factors Related To Stunting In Toddlers Aged 25- 59 Months In Puspasari Village, Puspahiyang, Tasikmalaya 2019
}

\author{
Risza Choirunnisa*, Triana Indrayani, Fitri Latipatul Anshor \\ National University, Jakarta, Indonesia \\ risza.choirunnissa@gmail.com
}

\begin{abstract}
The research aims to analyze factors related to stunting among toddlers aged 25-59 months at Puspasari Village, Puspahiyang District, Tasikmalaya Regency in 2019. It is also to find out the number of stunting, the frequency distribution of stunting based on LBW (low birth weight) history, exclusive breastfeeding, the knowledge of mother about complementary feeding, sanitation of the surrounding environment, and the family income, and the relation of all variables with stunting. Research design used in this research is quantitative with cross sectional design. The population of this research is toddlers aged 25-59 months. The research uses simple random with 74 toddlers aged 25-59 month as the sample at Puspasari Village. The instrument used is questionnaire.

The prevalence of stunting toddlers Puspasari Village is $22,3 \%$. The frequency of LBW history is $(12.2 \%)$, without exclusive breastfeeding is $(8,1 \%)$, less knowledgeable about complementary feeding is $(28,4 \%)$, unhealthy sanitation is $(79,7 \%)$, and low family income is $(86,5 \%)$. There is no significant relation of $\mathrm{LBW}$ ( $\mathrm{p}$ value $=0,596, \mathrm{OR}=0,686$ ) and exclusive breastfeeding ( $\mathrm{p}$ value $=0,890$, $\mathrm{OR}=0,889$ ) with stunting. There is a significant relation of the knowledge of mother about complementary feeding ( $\mathrm{p}$ value $=0,000, \mathrm{OR}=9,143$ ), sanitation ( $\mathrm{p}$ value $=0,004, \mathrm{OR}=6,261$ ), family income ( $\mathrm{p}$ value $=0,026, \mathrm{OR}=5,481$ ) with stunting.

There is a significant relation among mother knowledge about complimentary feeding, sanitation, and family income with stunting. It is expected that midwives hold a training to measure the height of toddlers.
\end{abstract}

Keywords: Stunting, Low Birth Weight, Exclusive Breastfeeding.

Received February, 15, 2020; Revised March 20, 2020; Accepted April 15, 2020 


\section{BACKGROUND}

The phenomenon of short toddlers, or generally referred to as stunting, is one of today's world's nutritional issues. In 2017, stunting was experienced by $22.2 \%$ or about 150.8 million children under five in the world (WHO, 2018).

Stunting prevalence data collected by the World Health Organization (WHO) shows that Indonesia is the third country with the highest prevalence in the Southeast Asia / South-East Asia Regional (SEAR) region. The average prevalence of stunting toddlers in Indonesia in 2005-2017 was 36.4\% (Ministry of Health of the Republic of Indonesia, 2018).

Based on Nutrition Status Monitoring (Indonesian: Pantauan Status Gizi/PSG) 2017, toddlers experiencing stunting in Indonesia were $26.6 \%$; $9.8 \%$ in the very short category and $19.8 \%$ in the short category. The first 1,000 days are actually the golden age of infants. In fact, there are still many toddlers aged 0-59 months experiencing nutritional problems (Katadata, 2018).

The prevalence of toddlers aged 0-59 months who experienced stunting in Tasikmalaya in 2019 was $18.3 \%$ of 115,634 toddlers, indicating that up to 21,161 toddlers had TB/U <-2SD (Tasikmalaya Health Office, 2019).

Data of Puspahiyang Community Health Center in Puspasari Village, where the study was conducted, showed that 51 out of 280 toddlers aged 25-59 months experienced stunting (Data of Puspahiyang Community Health Center, 2019).

There are many factors associated with stunting. A research conducted by Apri Sulistianingsih et al., (2018) showed that toddlers with a history of LBW are 17.063 times more likely to experience stunting than toddlers with a history of normal birth weight.

Furthermore, exclusive breastfeeding is also one of the most dominant factors of stunting. It is in line with the results of a research conducted by Khoirun Ni'mah et al., (2015) which pointed out that exclusive breastfeeding can prevent stunting in toddlers.

Knowledge and behavior of mothers in the practice of providing complementary food, that is done properly, affects the optimal growth and development which can prevent stunting. As a guide for complementary food delivery, WHO requires four items including punctuality, adequacy, responsiveness and safety (Hanindita, 2019).

The findings of a research conducted by Oliver Cumming et al., (2016) indicate that inadequate WASH (water, sanitation, hygiene) conditions have a significant detrimental effect on children's growth and development resulting from sustained exposure to enteric pathogens but also due to wider social and economic mechanisms.

Moreover, according to Ni Ketut Aryastami et al., (2017), poverty is another indirect variable that is significantly related to stunting.

According to the Minister of Health, Prof. dr. Nila Moeloek, Sp.M(K) (2018), as an attempt to prevent stunting, efforts that can be carried out by midwives since the mother is pregnant and giving birth include interventions with the first 1,000 days of a child's life, integrated ANC quality assurance, increasing deliveries at health facilities, organizing high-calorie, protein, and micronutrient feeding programs and eradicating helminthiasis. In addition, midwives' interventions for infants are by monitoring growth, Supplementary Feeding Progam, and early simulations of child development (Ministry of Health of the Republic of Indonesia, 2018).

Based on the description in the background above, the research problem of this study is "What are the Factors Associated with Stunting in Toddlers Aged 25-59 Months in Puspasari Village, Puspahiyang, Tasikmalaya in 2019?".

\section{METHOD}

This research utilized a cross sectional study design with the purpose of simultaneous or onetime measurements and observations. This study's population was all toddlers aged 25-59 months, as many as 280 in the Puspasari Village, Puspahiyang, Tasikmalaya in 2019. 
Sampling was performed using a non-probability technique that is Simple Random Sampling. There were 74 respondents obtained from the calculation using the Slovin formula. A questionnaire is the research instrument used by the researchers to collect data.

\section{RESULT}

1. Univariate Analysis

\begin{tabular}{llcc}
\hline \multicolumn{1}{c}{ VARIABLES } & \multicolumn{1}{c}{ INDICATORS } & $\mathrm{f}$ & $\%$ \\
\hline \multirow{2}{*}{ Stunting } & Stunting & 51 & 22.7 \\
& Not Stunting & 229 & 77.7 \\
\hline \multirow{2}{*}{ Low Birth Weight (Lbw) History } & Lbw & 9 & 12.2 \\
& Normal & 65 & 87.8 \\
\hline \multirow{2}{*}{ Exclusive Breastfeeding } & Not Exclusive Breastfeeding & 6 & 8.1 \\
& Exclusive Breastfeeding & 68 & 91.9 \\
\hline \multirow{2}{*}{ Knowledge Of Complementary Food } & Poor & 21 & 28.4 \\
& Good & 53 & 71.6 \\
\hline \multirow{2}{*}{ Environmental Sanitation } & Not Healthy & 59 & 79.7 \\
& Healthy & 15 & 20.3 \\
\hline \multirow{2}{*}{ Family Income } & Less & 64 & 86.5 \\
& More & 10 & 13.5 \\
\hline
\end{tabular}

Based on the results of univariate analysis, the incidence of stunted toddlers aged 25-59 months was $22.7 \%$. It means that 51 out of 280 toddlers stunted. There were 9 toddlers (12.2\%) aged 25-59 months who had a history of LBW. There were 6 toddlers $(8.1 \%)$ who did not get exclusive breastfeeding. Furthemore, there were 21 mothers $(28.4 \%)$ who had less knowledge. Moreover, 59 toddlers $(79.7 \%)$ came from unhealthy environmental sanitation. In addition, 64 people $(86.5 \%)$ had less family income.

\section{BIVARIATE ANALYSIS}

\begin{tabular}{|c|c|c|c|c|c|c|c|c|}
\hline \multirow{2}{*}{ VARIABLES } & \multicolumn{2}{|c|}{ Stunting } & \multicolumn{2}{|c|}{ Not Stunting } & \multicolumn{2}{|c|}{ Total } & \multirow{2}{*}{$\begin{array}{c}P \\
\text { value }\end{array}$} & \multirow{2}{*}{ OR } \\
\hline & $\mathrm{f}$ & $\%$ & $\mathrm{~F}$ & $\%$ & $F$ & $\%$ & & \\
\hline \multicolumn{9}{|l|}{ LBW History } \\
\hline LBW & 4 & 44.4 & 5 & 55.6 & 9 & 100 & \multirow{2}{*}{0.596} & \multirow{2}{*}{0.686} \\
\hline Normal & 35 & 53.8 & 30 & 46.2 & 65 & 100 & & \\
\hline \multicolumn{9}{|l|}{ Exclusive Breastfeeding } \\
\hline Not Exclusive Breastfeeding & 3 & 50.0 & 3 & 50.0 & 6 & 100 & \multirow{2}{*}{0.890} & \multirow{2}{*}{0.889} \\
\hline Exclusive Breastfeeding & 36 & 52.9 & 32 & 47.1 & 68 & 100 & & \\
\hline \multicolumn{9}{|c|}{ Mother's Knowledge Of Complementary Food } \\
\hline Poor & 18 & 85.7 & 3 & 14.3 & 21 & 100 & \multirow{2}{*}{0.000} & \multirow{2}{*}{9.143} \\
\hline Good & 21 & 39.6 & 32 & 60.4 & 53 & 100 & & \\
\hline \multicolumn{9}{|l|}{ Environmental Sanitation } \\
\hline Not Healthy & 36 & 61.0 & 23 & 39.0 & 59 & 100 & \multirow{2}{*}{0.004} & \multirow{2}{*}{6.261} \\
\hline Healthy & 3 & 20.0 & 12 & 80.0 & 15 & 100 & & \\
\hline \multicolumn{9}{|l|}{ Family Income } \\
\hline Less & 37 & 57.8 & 27 & 42.2 & 64 & 100 & \multirow{2}{*}{0.026} & \multirow{2}{*}{5.481} \\
\hline More & 2 & 20.0 & 8 & 80.0 & 10 & 100 & & \\
\hline
\end{tabular}




\section{STRADA Jurnal Ilmiah Kesehatan}

DOI: $10.30994 /$ sjik.v9i1.278

Based on the chi-square statistical test, a history of LBW was $(\mathrm{p}=0.596 \mathrm{OR}=0.686)$ and Exclusive breastfeeding was $(\mathrm{p}=0.890 \mathrm{OR}=0.889)$, so the null hypothesis $(\mathrm{Ho})$ was accepted. Therefore, it could be concluded that there was no significant relationship between LBW history and exclusive breastfeeding with stunting.

Additionally, the results of the chi-square statistical test showed that the mother's knowledge of complementary food was $(\mathrm{p}=0.000 \mathrm{OR}=9.143)$, Environmental Sanitation was $(p=0.004$ OR $=6.261)$ and Family Income was $(p=0.026$ OR $=5.481)$, resulting in the null hypothesis (Ho) was rejected. Therefore, it could be concluded that there was a significant relationship between mother's knowledge of complementary food, environmental sanitation and family income with stunting in Puspasari Village, Puspahiyang, Tasikmalaya in 2019.

\section{DISCUSSION}

\section{A. Relationship between LBW and Stunting}

Infants with LBW will grow and develop more slowly because they have undergone inter-uterine growth retardation since pregnancy, which will continue to the next age after birth. They experience slower growth and development than normal-born infants, and often fail to reach the growth levels where the children would have attained at their age. As a result, the growth of LBW infants will be disrupted. If this situation continues with inadequate feeding, frequent infections and poor health care, they are very likely to experience stunting (Proverawati and Ismawati, 2010).

The afforementioned theory is in accordance with a research conducted by Apri Sulistianingsih et al., (2018) who concluded that toddlers with a history of LBW are 17,063 times more likely to experience stunting than toddlers with a history of normal birth weight.

According to the researchers' analysis, although LBW infants experience growth retardation in the 1,000 First Day of Life, they still have time to pursue their growth. Providing adequate and optimal nutrition for LBW infants in the neonatal period will minimize the risk of stunting since LBW requires the management of special nutrients caused by limited food reserves. Thus, breastfeeding on demand is highly recommended. LBW infants who are not detected stunting after the age of 2 years can be sure to get optimal nutritional intake.

\section{B. Relationship between Exclusive Breastfeeding and Stunting}

Exclusive breastfeeding contributes significantly to children's growth and development, and stamina. Children that are exclusively breastfed should grow and develop optimally, as breast milk will meet their nutritional needs from birth to 24 months of age. Breast milk is needed for growth, development and survival of infants (Ministry of Health of Republic of Indonesia, 2014).

The results of a research conducted by Hasanah (2016) and Khoirun Ni'mah (2015) concludes that there is a significant relationship between exclusive breastfeeding and stunting.

Although some literature explains that exclusive breastfeeding is a preventive effort for stunting, according to the researchers' analysis, the reality shows that more infants who get exclusive breastfeeding experience stunting. It should be noted, however, that several other external factors affect the infants who get exclusive breastfeeding stunting such as infections and diseases, how parents/caregivers conduct parenting and provide complementary food, as well as sanitation conditions in the environment. 


\section{STRADA Jurnal Ilmiah Kesehatan}

DOI: $10.30994 /$ sjik.v9i1.278

\section{Relationship between Mother's Knowledge about Complementary Food and Stunting}

The period of complementary feeding to infants is entirely dependant on the mother's care and feeding. Mother's knowledge and attitudes, therefore, play an important role, as knowledge of complementary food and a good attitude towards complementary feeding help a mother to be able to arrange a good menu for her baby to consume (Bahri, 2011).

The results of this study are supported by a research conducted by Bahri (2011) which reported that knowledge is related to the attitudes of mothers in giving complementary food $(\mathrm{p}<0.05)$.

Any decision made by a mom in the process of giving complementary food is the result of the knowledge she has, according to the researchers' analysis. The energy needs of infants increase every day along with the development of physical abilities. This is due to the fact that after 12 months of age $60 \%$ of nutritional needs can only be fulfilled from the provision of complementary food.

\section{Relationship between Environmental Sanitation and Stunting}

Housing environments such as living conditions, lack of clean water supply, and inadequate sanitation are factors that can increase the risk of stunting (Oktarina, 2012).

The following are the results of the analysis of the researchers who focus on the condition of drinking water and the conditions of latrines in the community. In fact, the community generally utilizes water sources for drinking from wells while the distance of the water source to the septic tank is no more than 10 meters. Many families do not have their own latrines. Moreover, the condition of the defecation is outside; they build a special kind of defecation which triggers the spread of bacteria easily because of the condition of the latrine that is not in accordance with the rules and requirements.

\section{E. Relationship between Family Income and Stunting}

The quality and quantity of food consumed by families are affected by their low income. The food obtained is usually less varied, especially the food that functions in the child's growth such as sources of protein, vitamins, and minerals. It then increases the risk of malnutrition and these kind of limitations will also increase the risk of a toddler experiencing stunting (Hapsari, 2018).

According to the researchers 'analysis, the majority of family heads' work is farmers with a one-month income below the District/City Minimum Wage that affects the fulfillment of the nutritious food quality and quantity.

\section{CONCLUSIONS}

1. Univariate analysis results showed that the incidence of stunting in Puspasari Village was $22.3 \%$. It means that 51 out of 280 toddlers aged 25-59 months experienced stunting.

2. There is no relationship between the history of LBW and exclusive breastfeeding with stunting in toddlers aged 25-59 months in Puspasari Village.

3. There is a relationship between mother's knowledge of complementary food and stunting with OR $=9.143$, environmental sanitation, family income with stunting in toddlers aged 25-59 months in Puspasari Village. 


\section{STRADA Jurnal Ilmiah Kesehatan}

DOI: $10.30994 /$ sjik.v9i1.278

ISSN: 2252-3847 (print); 2614-350X (online)

Vol.9 No.1. May 2020. Page.170-182

\section{REFERENCES}

Bahri. 2011. Hubungan Pengetahuan dan Sikap Ibu dengan Pemberian MP-ASI di Kelurahan PB. Selayang II Kecamatan Medan Selayang. USU Repository. Medan.

Dinas Kesehatan Kabupaten Tasikmalaya. 2019. Data Statistik Status Gizi Balita di Kabupaten Tasikmalaya.

Hanindita, Meta. 2018. 567 Fakta tentang MPASI. Jakarta: Gramedia.

2018. Tanya Jawab tentang 1000 di Hari Pertama Kehidupan Anak. Jakarta: Gramedia

Hapsari, Windhi. 2018. Hubungan Pendapatan Keluarga, Pengetahuan Ibu Tentang Gizi, Tinggi Badan Orang Tua, Dan Tingkat Pendidikan Ayah Dengan Kejadian Stunting Pada Anak Umur 12-59 Bulan.

Katadata. 2018. Prevalensi Balita Stunting di Indonesia Tertinggi Kedua di Asean. Diakses https://databoks.katadata.co.id/datapublish/2018/11/22/prevalensi-stunting-balitaindonesia-tertinggi-kedua-di-asean [16 Oktober 2019]..

Kemenkes. 2018. Situasi Balita Pendek (Stunting) di Indonesia. Jakarta: Kemenkes RI.

Khoirun Ni'mah, dkk. 2015. Faktor yang Berhubungan dengan Kejadian Stunting. Surabaya: Universitas Airlangga.

Ni Ketut Ariyastami, et.al. 2017. Low birth weight was the most dominant predictor associated with stunting among children aged 12-23 months in Indonesia. BMC Nutrition Journal. 3:16.

Notoatmodjo. 2010. Metodologi Penelitian. Jakarta: Rineka Cipta. . 2014. Promosi Kesehatan dan Perilaku Kesehatan. Jakarta: Rineka Cipta.

Oktarina, Zilda. 2012. Hubungan Berat Lahir dan Faktor-faktor Lainnya dengan Kejadian Stunting pada Balita Usia 25-59 Bulan. Jurnal Gizi dan Pangan Vol 8 No3 [16 Oktober 2019].

Oliver Cumming, et.al. 2016. Can water, sanitation and hygine help stunting current evidence and policy implications. Maternal \& Child Nutrition published by JohnWiley \& Sons Ltd Maternal \& Child Nutrition (2016), 12 (Suppl. 1), pp. 91105.

Proverawati, A. \& Ismawati, C. 2010. Berat Badan Lahir Rendah. Yogyakarta: Muha Medika.

Puskesmas Puspahiyang. 2019. Data Balita Stunting di Desa Puspasari. Tasikmalaya.

Rahmadi, Antun. 2018. Hubungan Berat Badan Dan Panjang Badan Lahir Dengan Kejadian Stunting Anak 12-59 Bulan Di Provinsi Lampung. Jurnal Keperawatan Poltekkes Tanjungkarang Vol 12 No.2 [16 Oktober 2019].

Soetjiningsih. 2013. ASI Petunjuk untuk Kesehatan. Jakarta: EGC.

Sugiyono. 2017. Metode Penelitian Kuantitatif, Kualitatif dan R\&D. Bandung: Alfabeta.

Sulistianingsih, Apri dkk. 2018. ASI eksklusif dan berat lahir berpengaruh terhadap stunting pada balita 2-5 tahun di Kabupaten Pesawaran. Jurnal Gizi Klinik Indonesia Vol 15 No 2 - Oktober 2018 (45-51).

WHO. 2018.Stunting is a nutshell. Diakses https://www.who.int/nutrition/healthgrowthproj_stunted_videos/en/ [18 Nopember 2019] 